Article

\title{
Factors Influencing U.S. Charitable Giving during the Great Recession: Implications for Nonprofit Administration
}

\author{
Jerry D. Marx * and Vernon B. Carter \\ Department of Social Work, University of New Hampshire, Durham, NH 03824, USA; \\ E-Mail: Vernon.Carter@unh.edu \\ * Author to whom correspondence should be addressed; E-Mail: Jerry.Marx@ unh.edu; \\ Tel.: +1-207-752-0347; +1-603-862-4728.
}

Received: 26 May 2014; in revised form: 7 August 2014 / Accepted: 23 August 2014 /

Published: 28 August 2014

\begin{abstract}
The purpose of this study is to examine factors influencing U.S. charitable giving during the first full year of the Great Recession. Demand on the services of human service nonprofits typically escalates during periods of extreme economic downturn; thus donations to agencies serving the most vulnerable groups - the young, the old, and the frail-become increasingly important. The study sample consisted of 8690 U.S. respondents. Results indicate the growing importance of computer ownership and the continuing importance of combined purpose agencies in assisting the needy in hard times. Suggestions for both future research and nonprofit administrative practice regarding charitable giving are provided.
\end{abstract}

Keywords: nonprofit administration; charitable giving; federated fundraising; international aid; online giving

\section{Introduction}

When the Obama Administration took office, it faced the worst U.S. economy since the Great Depression. Over three million jobs had been lost in 2008; over three million households had received foreclosure notices on their homes in that year [1]. The recession lasted about two years, roughly 2008-2009. Given the massive need created by the Great Recession, the demand on the services of human service nonprofit agencies, especially organizations serving the most needy citizens, soared. 
These organizations include soup kitchens, the Red Cross, the Salvation Army, homeless shelters. The ability of these voluntary community agencies to meet this growing public need through increased service provision, in turn, depended to a significant extent on the level of charitable donations to such agencies. Yet, according to USA Giving 2009, total giving to human services in the U.S. (adjusted for inflation) between 2007 and 2009 dropped by 13.5\% [2]. While donations to most types of beneficiary organizations declined during this period, the drop in giving to human services was the largest. The only category to actually see an increase during this period was giving to international affairs, which increased by $3.6 \%$.

Social exchange theory posits that no charitable gift is purely altruistic (i.e., a one way exchange) [3]. Rather, like all social exchanges, charity is a two-way exchange motivated by benefits to each party in the exchange - the giver and the beneficiary. With this theory in mind, American philanthropists have been criticized in recent years for giving too great a share of their total giving to education, health, and the arts from which they receive direct benefit, and not enough to human services serving the poor. Consequently, a "charitable divide" between the former and latter beneficiaries has emerged [4]. To the extent that social exchange theory, in fact, provides an explanation for the charitable impulse, other factors influencing charitable giving to the needy must be explored.

The Great Recession hurt many Americans, yet none more than the most vulnerable groups such as disadvantaged youth, the frail and sick, as well as the homeless and hungry. Consequently, this study examines U.S. household donations during the recession to organizations serving these groups. Specifically, we examined factors influencing charitable giving to combined purpose organizations such as United Way and Catholic Charities, youth service organizations and organizations serving those in need of food, shelter, and other basic necessities. While the negative impact on the homeless was immediately visible, vulnerable youth may be negatively affected by deprivation related to the recession for years to come. Agencies such as United Way and Catholic Charities distribute funds to organizations serving youth, the homeless and hungry as well as to providers assisting the elderly. Furthermore, given the fact that international aid organizations serve some of the world's most poverty stricken nations, the study will also examine donations to this fourth category of beneficiary.

\section{Past Research}

The purpose of this empirical literature review is to identify potentially significant predictors in our dataset of U.S. charitable giving during the recession year of 2008. These include race, sex, income, volunteer experience, location of residence, age, household size, tax status, workplace giving options, household wealth, religious affiliation, education level, home ownership, employment status, marital status, and computer ownership. The literature on each of the preceding variables is extensive, and thus, what follows is a representative study finding for each of the variables.

In an earlier study of the charitable giving practices of 498 black business owners in the U.S., Edmondson and Carroll found that survey participants (94.7\%) believed giving to youth programs was among the charitable activities that produced the most positive impact on the black community. It should be noted that study participants were primarily male $(79.7 \%)$, college educated (78\%), and middle-aged (average age was 46.7 years old) [5]. 
In a 2000 study by Marx, the author found that, in a representative sample of 2719 U.S. adults aged 18 and over, those who donated to human service organizations were more likely to be women, white, have a higher income, and volunteer in human services [6].

The Center on Philanthropy and Civil Society in a 2003 report stated that African American families tend to be urban dwellers, are less likely to participate in planned giving, are younger than the median U.S. age, have more children under 18 at home, and are more likely to have extended family residing in the household [7] (pp. 12-13). The last three factors are suspected to negatively influence the amount of wealth in these families. Given the findings of some studies in this review regarding the positive relationship between wealth and charitable giving, this finding is important [7].

Bekkers and Wiepking reviewed over 500 empirical articles on charitable giving published up to August of 2007 [8]. The review suggests the following eight factors to be particularly significant in motivating charitable giving: awareness of existing need, being asked to give, potential costs and benefits to the donor (such as tax benefits), altruism (i.e., caring about others), reputation and social status, positive psychological benefits (such as a positive self-image and the "joy of giving"), personal values (related to one's vision of an ideal world), and efficacy (related to confidence in nonprofits and "making a difference"). An additional finding of note was that when employers match their employee gifts, employees tend to give more.

Carter and Marx, using the Panel Study of Income Dynamics, a national U.S. dataset, examined factors influencing African American charitable giving [9]. The representative sample contained 5619 households. Household size had a significant positive influence on African American giving to federated campaign organizations such as United Way and the United Jewish Appeal. Household wealth had a significant positive influence on giving by this population to youth service organizations as well as neighborhood improvement organizations. The act of volunteering had a positive influence on giving to federated campaign organizations, youth services, and organizations providing basic necessities to the needy, as well as on giving to neighborhood organizations and health services. Interestingly, the authors found that neither wealth nor income had a significant effect on African American giving to federated campaigns and youth-service organizations.

Wang and Graddy examined U.S. charitable giving using the 2000 Social Capital Community Benchmark survey [10]. The survey was done nationally using random-digit-dialing and telephone interviews. Because of missing data, this study used 1946 interviews from the total study population of 3003. The authors define "social capital" in terms of one's social network of friends, family, and organizations as well as their trust in authority and in other people generally. The study found that individuals who volunteer more are more likely to give money also. Those for whom religion is important are more likely to donate to religious organizations, but "religiosity" did not have a significant impact on giving to secular organizations such as United Way. Those with a college level education gave more to religious and secular organizations than those with less education; similarly those with a middle or high income gave more to religious and secular organizations than those with low incomes. Finally, this study found that homeownership influenced religious giving, but not giving to secular organizations.

In a 2008 study of 224 Hispanic Americans, Marx and Carter found that Hispanic donors who used payroll deduction were eight times as likely to give to human services, than Hispanic givers who did 
not use payroll deduction [11]. In addition, Hispanic givers who volunteered their time were twice as likely to donate to youth development as Hispanic donors who did not volunteer.

Wiepking used data from the "Giving in the Netherlands Panel Study 2008" to examine which categories of nonprofit organizations receive donations from specified groups of people [12]. This biannual longitudinal study collected information on total household giving to charity in 2007. Charities with an international focus showed an increased probability of receiving donations from "left-leaning" donors and donors with high levels of confidence in charitable organizations. Donors with average or high socio-economic status gave more often to cultural organizations.

Using data from the Knowledge Networks survey, Osili, Hirt, and Raghaven looked at the influence of firm size and an established tradition of workplace campaigns on employee charitable giving [13]. While the finance and education sectors were most likely to offer a workplace giving campaign, the retail sector was the least likely to do so. Workers at smaller firms were less likely to be offered a workplace campaign giving option. Individual employees without workplace campaigns were less likely to have a bachelor's degree and had lower income and wealth levels. In addition, the authors found that workplace donors had significantly higher confidence in nonprofit organizations than non-donors.

Yoruk examined race and gender differences in the probability of being asked to donate to a cause [14]. Using nonlinear decomposition techniques with data on U.S. giving collected between 1992 and 2001, the study found that blacks are 12\% less likely than whites to be asked to give, while nonwhite Hispanics were $26 \%$ less likely to be asked to give. In the case of blacks, most of this difference is explained by education and income. The author also found sex, age, family size, employment and marital status, and home ownership to be significant determinants of this difference between blacks and whites. With nonwhite Hispanics, the "observable differences" between whites and nonwhite Hispanics explained 55\%-69\% of the gap in being asked to give, while age, sex, income, and education contributed to the difference as well.

In a 2011 study of the giving differences between high net worth women and men (average household wealth in the study was $\$ 12.2$ million; average household income was $\$ 639,924$ ), the Center on Philanthropy at Indiana found that women were more likely than men to report that they give when they know the beneficiary is efficient in the use of the donation $(80.5 \%$ vs. $69.2 \%)$ and to give back to the community $(78.2 \%$ vs. $63.3 \%)$ [15]. Men were more likely than women in the study to support the same causes from year to year $(67.9 \%$ vs. $59.5 \%)$ and to designate their largest gifts to capital projects (15.9\% vs. $10.8 \%)$. Most of both men $(55.7 \%)$ and women $(60.2 \%)$ in the study stated that their largest gifts most likely go to support general operating expenses.

Wiepking and Breeze examined the impact of money perceptions on charitable giving in the Netherlands [16]. The authors used data from the "Giving in the Netherlands Panel Study 2008." The authors found that people who worry more about their financial status tend to donate lower amounts to charity-even when accounting for actual financial resources. This is important since some people may in fact have substantial financial resources, yet feel financially insecure. The authors also found that homeowners donate on average 51 per cent more money to charities than renters, and people who receive income from wealth donate 67 per cent more money than people who do not receive this type of income. 
Kemp, Kennet-Hensel, and Kees in a 2013 study of 84 nonstudent adults in the Austin, Texas area, found that a charitable giving appeal that induced sympathy was more effective with women than with men in terms of an expressed intent to give [17].

Using data from a survey of residents in southeastern North Carolina, Clerkin, Paarlberg, Christensen, Nesbit, and Tschirhart published a study in 2013 examining the impact of participants' "sense of community," social ties, and their regional culture on their charitable giving [18]. Regarding culture, regional cultural perspectives tend to vary regarding the role of government verses nonprofit civic organizations in meeting community needs. The sample size for the study was 335,233. The authors found that the longer the resident lived in southern North Carolina, the more they donated to local, secular nonprofit agencies. Similarly, the larger the resident's social network, the greater the person's volunteering and charitable giving. In addition, married residents donated more than unmarried residents; retirees volunteered more of their time, but tended to donate less money to local secular nonprofits.

Another study analyzed giving between 2007 and 2010 using the FirstGiving website [19]. Despite the recession, online giving on the site grew 130\% during four year period. Most of the online donors were between 39 and 50 years of age, but the size of the average donation increased with the age of the donor up until the age of 67 . The study also found a positive relationship between volunteering and giving and that the higher the household income, the larger the gift amount.

Finally in 2014, Mano published a secondary analysis of PEW data finding that participation in social media (including Facebook), network blogging, and journaling significantly increased charitable donations [20].

Building on this previous research, this study examines U.S. charitable giving during the Great Recession to agencies benefitting society's most vulnerable groups. Because the factors influencing giving to different categories of beneficiary may vary, we looked at each category of human service agency separately. More specifically, the following research questions were examined:

1. What factors influence U.S. charitable giving to organizations serving the needy?

2. What factors influence U.S. charitable giving to organizations serving youth?

3. What factors influence U.S. charitable giving to international organizations?

4. What factors influence U.S. charitable giving to combined purpose organizations?

\section{Methods}

\subsection{Data}

The study uses the Panel Study of Income Dynamics (PSID) data to analyze the effects of several independent variables on giving by U.S. households to organizations that serve the needy. The PSID is a public use dataset produced and distributed by the Institute for Social Research at the University of Michigan in Ann Arbor, MI. Created to help evaluate President Lyndon Johnson's War on Poverty, the PSID is essentially a longitudinal survey that has followed a representative sample of 4800 families and their descendants since 1968. The PSID family and individual files contain data on various demographic characteristics as well as other factors potentially influencing household charitable giving. The current study extracted data from the 2009 Public Use Family file, which included 
household charitable donations in 2008 - the first full year of the recession and a year in which this data was updated.

The paper's descriptive analyses use an unweighted cross-sectional sample of all PSID responding households in 2009. The study's multivariate analyses use a weighted (see Heeringa, Berglund, and Khan, 2011 for detailed descriptions of the PSID weights) longitudinal sample consisting of 8690 PSID individuals residing in the 5709 interviewed households at the time of the 2009 interview [21]. The household is used as the unit of measurement.

\subsection{Measures}

\subsubsection{Dependent Variables}

Regarding the dependent variables, a questionnaire item asked whether or not the family head (or anyone in the family) made any donations (during 2008) to a specific charitable organization. The specific organizations we are exploring in this study are those who benefit the Needy, Youth, International groups, and Combined Purpose organizations such as United Way. Further descriptions of the dependent variables are found in Table 1.

Table 1. Dependent Variable descriptions.

\begin{tabular}{|c|c|c|}
\hline Variable name & Description & Coding \\
\hline International & $\begin{array}{l}\text { An organization that provides international aid or promotes } \\
\text { world peace? Such as, international children's funds, disaster } \\
\text { relief, or human rights? }\end{array}$ & $1=$ Yes, $0=$ No \\
\hline Needy & $\begin{array}{l}\text { An organization that helps people in need of food, shelter, } \\
\text { or other basic necessities? }\end{array}$ & $1=$ Yes, $0=$ No \\
\hline Youth & $\begin{array}{l}\text { An organization that provides youth or family services? } \\
\text { Such as to scouting, boys' and girls' clubs, sports leagues, } \\
\text { Big Brothers or Sisters, foster care, or family counseling? }\end{array}$ & $1=$ Yes, $0=$ No \\
\hline Combo & $\begin{array}{l}\text { An organization that served a combination of purposes? For } \\
\text { example, the United Way, the United Jewish Appeal, the } \\
\text { Catholic Charities, or your local community foundation? }\end{array}$ & $1=$ Yes, $0=$ No \\
\hline
\end{tabular}

\subsubsection{Independent Variables}

There were sixteen independent variables: age, race, gender, Latino ethnicity; number of people and children in household; head of households' marital status, religious preference, education level, employment status, access to a computer; region in which head of household resides, whether or not household lives in a city; total annual medical costs, households income, and wealth. Further descriptions of the independent variables are found in Table 2. 
Table 2. Independent variable descriptions.

\begin{tabular}{|c|c|c|}
\hline Variable name & Description & Coding \\
\hline Agehead & Age of head of family & $1=0 / 39,2=40 / 59,3=60 / 79,4=80 / \mathrm{max}$ \\
\hline Race/RaceWF & Race of the head of the family/Wife's race & $\begin{array}{l}1=\text { White, } 2=\text { Black, } 3=\text { AI } / \mathrm{AN}, 4=\text { Asian, } \\
5=\text { Native Hawaiian }\end{array}$ \\
\hline Latino/Latina & $\begin{array}{l}\text { Spanish descent head of the family/Spanish } \\
\text { Wife }\end{array}$ & $1=$ yes, $0=$ No \\
\hline Gender & Sex of the head of the family & Male $=1 ;$ Female $=0$ \\
\hline Household & Number of people in household & $1=$ Two or less people $;=3$ or more people \\
\hline Child & Number of children in household & $1=1$ Child, $0=2$ or more Children \\
\hline Married & Marital status & $1=$ yes, $0=$ No \\
\hline Religious/(WF) & $\begin{array}{l}\text { Head of family and/or wife expresses a } \\
\text { religious preference }\end{array}$ & $1=$ yes, $0=$ No \\
\hline RetireWF & The age wife thinks she will stop working & \\
\hline Edlevel & Head's education level & $\begin{array}{l}1=\text { Not HS Grad, } 2=\text { HS Grad, } 3=\text { More } \\
\text { than HS Grad }\end{array}$ \\
\hline Employed & Employed & $1=$ yes, $0=$ No \\
\hline Computer/(WF) & Head of family and/or wife owns a computer & $1=$ yes, $0=$ No \\
\hline City & Head lives in city of $1,000,000$ people or more & $1=$ yes, $0=$ No \\
\hline Famincome & $\begin{array}{l}\text { Annual Household income in dollars that has } \\
\text { been categorized }\end{array}$ & $\begin{array}{l}1=\min / 25,000,2=25,001 / 50,000 \\
3=50,001 / 100,000,4=100,001 / \max \end{array}$ \\
\hline Wealthy & $\begin{array}{l}\text { Continuous variable sum of all assets in } \\
\text { dollars including home equity that has been } \\
\text { categorized }\end{array}$ & $\begin{array}{l}1=\min / 25,000,2=25,001 / 100,000 \\
3=100,001 / 500,000,4=500,001 / \max \end{array}$ \\
\hline
\end{tabular}

\section{Statistical Analysis}

Univariate analyses were conducted to provide descriptive statistics of all variables; bivariate and multivariate analyses were computed to examine the relationships among variables. Regarding multivariate analyses and more specifically logistic regression analyses, an initial model was created by running logistic regression analyses for each independent variable of interest and giving to organizations serving the needy, youth organizations, international organizations, and combined purpose agencies such as United Way (Univariate analysis). The results generated odds ratios, standard errors, $p$ values and confidence intervals. Those variables that were found to have a $p$ values $\leq 0.05$ were entered into a multivariate logistic regression analysis (Multivariate analysis) to identify those variables that were independently associated with each of the dependent giving variables.

Subsequent analyses were conducted to develop a more parsimonious model. It is appropriate to use backward step regression when conducting exploratory analyses [22]. Those variables that were found to have a $\mathrm{p}$ values greater than .05 were removed unless they were thought to be important to giving to one of the four beneficiary categories of interest.

\section{Findings}

\subsection{Sample Characteristics}

There were 8690 respondents in the sample of whom $60 \%$ were White $(n=5171) ; 35 \%$ were African-American $(n=3023) ; 0.1 \%$ were Asian $(n=112)$, Pacific Islander $(n=9) ; 0.67 \%$ were 
American Indian/Alaskan Native $(\mathrm{n}=58) ; 6 \%$ were ethnically Latino $(\mathrm{n}=526)$ and $5 \%$ were Latina $(n=450)$ (the percentages are rounded off from the results reported in Table 3$)$.

Table 3. Household characteristics of persons who gave to a charitable organization in 2008; $\mathrm{N}=8,690$ (Unweighted).

\begin{tabular}{|c|c|c|c|c|}
\hline Variables & $\mathbf{N}$ & $\%$ & Mean/Median & SD \\
\hline \multicolumn{5}{|l|}{ Head of Household Characteristics } \\
\hline \multicolumn{5}{|l|}{ Race/ethnicity } \\
\hline White & 5171 & 59.50 & & \\
\hline Age of Whites & & & $46.56 / 45$ & 17.11 \\
\hline Blacks & 3023 & 34.79 & & \\
\hline Age of Blacks & & & $42.98 / 42$ & 23.38 \\
\hline Asian & 112 & 1.29 & & \\
\hline American Indian, Alaskan Native & 58 & 0.67 & & \\
\hline Native Hawaiian/Pacific Islander & 9 & 0.10 & & \\
\hline Other & 241 & 2.77 & & \\
\hline Latino & 526 & 6.05 & & \\
\hline Age of Latinos & & & $41.81 / 40.5$ & 15.10 \\
\hline Latinas & 450 & 5.18 & & \\
\hline Age of Latinas & & & $42.39 / 41$ & 13.61 \\
\hline \multicolumn{5}{|l|}{ Gender } \\
\hline Male & 6001 & 69.06 & & \\
\hline Married/living with partner & 4131 & 47.54 & & \\
\hline ReligHD & 7189 & 82.73 & & \\
\hline ReligWF & 3856 & 44.37 & & \\
\hline RetireWF & & & $61.3 / 62$ & 5.51 \\
\hline$>$ HS Grad & 4023 & 46.29 & & \\
\hline HS grad & 2713 & 31.22 & & \\
\hline$<$ HS grad & 1517 & 17.46 & & \\
\hline \multicolumn{5}{|l|}{ Household Characteristics } \\
\hline Number of persons in household & & & 2.64 & 1.48 \\
\hline Number of children in household & & & 0.82 & 1.17 \\
\hline Employed-yes & 5810 & 66.86 & & \\
\hline Computer-own & 6309 & 72.60 & & \\
\hline ComputerWF-own & 3852 & 44.33 & & \\
\hline City-resides & 2348 & 27.02 & & \\
\hline Income & & & $68,923 / 49,700$ & 105,425 \\
\hline Wealth & & & $250,534 / 27,500$ & $1,819,245$ \\
\hline
\end{tabular}

* Note: The exact percentages may be off because of missing data. It would be too cumbersome to note missing data for every analysis. The authors consider the data to be Missing Completely at Random (MCAR). Lynch (March, 2003) said MCAR data can be ignored [23].

The heads of the households reported their marital status as 48\% married or living with a partner $(\mathrm{n}=4131)$. (Note that the questionnaire instrument refers to the household head's spouse or partner as "wife;" therefore we use the same term yet recognize the diversity of household couples.) The percentage of heads of households who reported being religious was $83 \%$ ( $n=7,189)$. Of the 4131 heads of households who reported having a wife, 3856 of those women said they were religious (44\% of the sample). The educational status for the head of household was as follows: $46 \%$ were more than 
high school graduates $(\mathrm{n}=4023), 31 \%$ were high school graduates $(\mathrm{n}=2713)$, and $17 \%$ less than high school graduates $(\mathrm{n}=1517)$. The average number of persons living in the household was 3 $(\mathrm{SD}=1.48)$ and the average number of children was $1(\mathrm{SD}=1.17)$.

The employment rate of household heads was $67 \%(\mathrm{n}=5810) ; 73 \%$ owned a computer $(\mathrm{n}=6309)$ and $27 \%$ lived in a large metropolitan city (2348). The mean income for the head of household was $\$ 68,923(\mathrm{SD}=\$ 105,425)$ and the mean wealth and equity was $\$ 250,534(\mathrm{SD}=\$ 1,819,245)$.

\subsection{Research Question \#1: What Factors Influence U.S. Charitable Giving to Organizations Serving the Needy?}

The previously described set of independent variables was tested for possible associations with the dependent variable, charitable giving to U.S. organizations serving people in need of basic necessities like food and shelter. (See Table 4) Chi-square results showed several independent variables associated with giving to organizations serving the most needy Americans. These include total family (i.e., household) income, race of the head of the household, whether or not the household head was Latino, education level of the household head, wife's religion, whether or not the household head owns a computer, whether or not the wife of the household head owns a computer, and total household medical costs. What is more, several variables approached significance at the $p<0.05$ level. These independent variables were age of household head, employment status of the household head, and the household urbanicity (i.e., household resides in urban area).

The results of subsequent analysis using backward step regression showed several of these independent variables to be significant predictors of U.S. household charitable giving to U.S. organizations providing basic necessities to the needy. (See Table 5) These predictors were being ethnically Latino, education level, computer ownership, and total household wealth. The factors in the regression analyses are predictors of Americans making donations to these human service organizations. The results of the analysis are in the form of odds ratios (OR). The odds ratio and beta coefficient are interchangeable statistics in a logistic regression. The odds ratio lets the reader know the likelihood that Americans are going to give a donation. A predictor that has an OR equal to 2.0 for example, indicates a person is twice as likely to give a donation. While an OR of 0.55 indicates a person is $45 \%$ less likely to make a donation. Latinos were $45 \%$ less likely ( $\mathrm{OR}=0.54 ; p=0.002$ ) compared to non-Latinos to make a charitable donation. In this case, household heads with more than a high school education were 1.43 times $(\mathrm{OR}=1.43 ; p=0.00)$ as likely to make a charitable donation to an organization providing basic necessities like food and shelter to the needy. Those who owned a computer were 1.26 times $(\mathrm{OR}=1.26 ; p=0.044)$ as likely to make a charitable gift to such organizations. In addition, those households with wealth estimated between $\$ 100,001$ and $\$ 500,000$ were 1.43 times $(\mathrm{OR}=1.43 ; p=0.00)$ as likely to make a donation, while households with over a half million dollars in wealth were 1.47 times $(\mathrm{OR}=1.47 ; p=0.002)$ as likely to give to organizations serving the most needy. 
Table 4. Bivariate analysis of independent variables association with charitable organizations (weighted).

\begin{tabular}{|c|c|c|c|c|c|c|c|c|c|c|c|c|}
\hline \multirow[b]{2}{*}{ Variables } & \multicolumn{2}{|c|}{$\begin{array}{c}\text { Donate to } \\
\text { International }\end{array}$} & \multicolumn{4}{|c|}{ Donate to Needy } & \multicolumn{2}{|c|}{ Donate to Youth } & \multicolumn{4}{|c|}{$\begin{array}{c}\text { Donate to } \\
\text { Combo }\end{array}$} \\
\hline & $\%$ Yes & $\%$ No & $\chi^{2}$ & $\%$ Yes & $\%$ No & $\chi^{2}$ & $\%$ Yes & $\%$ No & $\chi^{2}$ & $\%$ Yes & $\%$ No & $\chi^{2}$ \\
\hline \multicolumn{13}{|c|}{ Head of Household Characteristics } \\
\hline Age years & & & $3.37 *$ & & & 2.42 & & & $6.77 *$ & & & $3.36 *$ \\
\hline $0 / 39$ & 26.24 & 37.07 & & 35.17 & 37.13 & & 28.18 & 37.95 & & 32.59 & 38.38 & \\
\hline $40 / 59$ & 45.64 & 40.65 & & 39.68 & 42.18 & & 42.45 & 40.69 & & 44.26 & 39.06 & \\
\hline $60 / 79$ & 22.36 & 18.59 & & 20.81 & 17.18 & & 24.31 & 17.71 & & 19.44 & 18.56 & \\
\hline $80 / \max$ & 5.76 & 3.70 & & 4.34 & 3.51 & & 5.05 & 3.66 & & 3.72 & 4.00 & \\
\hline Race/ethnicity & & & $5.45 *$ & & & $4.34 *$ & & & $5.43 *$ & & & 0.76 \\
\hline White & 74.43 & 66.86 & & 70.94 & 64.22 & & 75.56 & 65.73 & & 69.23 & 66.31 & \\
\hline African American & 14.29 & 27.8 & & 24.1 & 29.26 & & 19.33 & 28.35 & & 25.53 & 27.58 & \\
\hline Asian & 3.58 & 1.58 & & 1.30 & 2.11 & & 0.53 & 1.98 & & 1.48 & 1.88 & \\
\hline Latinos & 4.93 & 5.55 & 0.12 & 3.73 & 7.11 & $13.25 *$ & 3.91 & 5.83 & 2.51 & 3.31 & 6.84 & $13.55 *$ \\
\hline Latinas & 5.46 & 4.96 & 0.08 & 3.56 & 6.29 & $9.81 *$ & 3.41 & 5.33 & 2.81 & 3.19 & 5.74 & $4.71 *$ \\
\hline \multicolumn{13}{|l|}{ Gender } \\
\hline Male & 75 & 74.26 & 0.05 & 74.21 & 74.53 & 0.04 & 77.80 & 73.58 & 3.42 & 77.11 & 72.60 & $6.43 *$ \\
\hline Married & 62.73 & 59.61 & 0.72 & 61.37 & 58.41 & 2.29 & 68.09 & 58.06 & $15.35 *$ & 64.49 & 56.96 & $14.10 *$ \\
\hline Relig Pref Head & 87.24 & 88.97 & 0.54 & 89.44 & 88.21 & 0.94 & 91.46 & 88.28 & 3.72 & 90.45 & 87.87 & $3.88 *$ \\
\hline Educational status & & & $15.07 *$ & & & $18.45 *$ & & & $7.97 *$ & & & $11.3 *$ \\
\hline$>$ HS Grad & 78.72 & 57.53 & & 65.05 & 53.71 & & 67.68 & 57.23 & & 64.44 & 55.78 & \\
\hline HS grad & 17.05 & 29.96 & & 26.19 & 31.59 & & 23.84 & 30.15 & & 26.96 & 30.30 & \\
\hline$<$ HS grad & 4.23 & 12.51 & & 8.75 & 14.71 & & 8.49 & 12.62 & & 8.60 & 13.92 & \\
\hline
\end{tabular}


Table 4. Cont.

\begin{tabular}{|c|c|c|c|c|c|c|c|c|c|c|c|c|}
\hline \multirow[b]{2}{*}{ Variables } & \multicolumn{2}{|c|}{$\begin{array}{c}\text { Donate to } \\
\text { International } \\
\end{array}$} & \multicolumn{4}{|c|}{ Donate to Needy } & \multicolumn{2}{|c|}{ Donate to Youth } & \multicolumn{4}{|c|}{$\begin{array}{c}\text { Donate to } \\
\text { Combo }\end{array}$} \\
\hline & $\%$ Yes & $\% \mathrm{No}$ & $\chi^{2}$ & $\%$ Yes & $\% \mathrm{No}$ & $\chi^{2}$ & $\%$ Yes & $\%$ No & $\chi^{2}$ & $\%$ Yes & $\% \mathrm{No}$ & $\chi^{2}$ \\
\hline \multicolumn{13}{|c|}{ Household Characteristics } \\
\hline \multicolumn{13}{|c|}{ Number of persons in household } \\
\hline 2 or less (yes) & 64.08 & 54.92 & $5.97 *$ & 57.18 & 54.32 & 2.09 & 56.68 & 55.41 & 0.24 & 56.84 & 54.91 & 0.89 \\
\hline Employed & 69.16 & 72.04 & & 71.23 & 72.39 & 1.88 & 71.19 & 71.92 & $4.38 *$ & 75.67 & 69.43 & $11.42 *$ \\
\hline Computer-own & 87.33 & 81.42 & $4.04 *$ & 85.23 & 78.76 & $18.12 *$ & 87.87 & 80.54 & $13.08 *$ & 87.66 & 78.26 & $36.19 *$ \\
\hline City-resides & 30.38 & 26.3 & 1.49 & 26.83 & 26.31 & 0.09 & 20.99 & 27.78 & $8.65 *$ & 25.36 & 27.26 & 1.10 \\
\hline Medcosts & & & $5.58 *$ & & & $4.75 *$ & & & $3.22 *$ & & & $2.98 *$ \\
\hline $\min / 25,000$ & 12.39 & 18.1 & & 17.2 & 18.07 & & 13.42 & 18.57 & & 16.44 & 18.31 & \\
\hline $2501 / 15,000$ & 40.92 & 29.12 & & 29.86 & 30.02 & & 31.08 & 29.75 & & 32.64 & 28.35 & \\
\hline $15,001 / 50,000$ & 19.06 & 15.93 & & 18.93 & 13.68 & & 19.57 & 15.45 & & 17.27 & 15.49 & \\
\hline $50,001 / \max$ & 27.63 & 36.84 & & 34.01 & 38.24 & & 35.93 & 36.23 & & 33.65 & 37.85 & \\
\hline Income & & & $7.00 *$ & & & $7.97 *$ & & & $10.5 *$ & & & $23.47 *$ \\
\hline $\min / 25,000$ & 10.77 & 12.86 & & 11.16 & 14.07 & & 8.48 & 13.59 & & 7.45 & 15.83 & \\
\hline $25,001 / 50,000$ & 15.83 & 24.09 & & 20.74 & 25.92 & & 19.00 & 24.41 & & 20.33 & 25.45 & \\
\hline $50,001 / 100,000$ & 30.53 & 35.44 & & 35.46 & 34.82 & & 33.67 & 35.37 & & 36.07 & 34.50 & \\
\hline $100,001 / \max$ & 42.87 & 27.61 & & 32.64 & 25.19 & & 38.84 & 26.64 & & 36.15 & 24.23 & \\
\hline Wealth & & & $12.61 *$ & & & $10.46 *$ & & & $21.33 *$ & & & $11.95 *$ \\
\hline $\min / 25,000$ & 23.83 & 35.76 & & 31.52 & 37.86 & & 24.01 & 37.15 & & 29.76 & 37.91 & \\
\hline $25,001 / 50,000$ & 16.03 & 20.30 & & 17.68 & 22.12 & & 16.89 & 20.62 & & 19.46 & 20.33 & \\
\hline $100,001 / 500,000$ & 30.58 & 30.21 & & 33.19 & 27.44 & & 33.42 & 29.54 & & 31.01 & 29.72 & \\
\hline $500,001 / \max$ & 29.55 & 13.73 & & 17.61 & 12.58 & & 25.68 & 12.69 & & 19.78 & 12.04 & \\
\hline
\end{tabular}

Source: Weighted data from the Panel Study of Income Dynamics; * $p<0.05$; Note: to conserve space the data for the nonstatistically significant variables wife, American Indian/Alaskan Native, Native Hawaiian/Pacific Islander, Other (race/ethnicity), Number of persons in household-3 or more (no), and Number of children in household were not shown in table. 
Table 5. Logistic models predicting charitable giving to needy organizations.

\begin{tabular}{|c|c|c|c|c|c|c|}
\hline & \multirow{2}{*}{\multicolumn{2}{|c|}{$\begin{array}{c}\text { Univariate analysis } \\
\text { Model } 1\end{array}$}} & \multirow{2}{*}{\multicolumn{2}{|c|}{$\begin{array}{c}\text { Multivariate analysis } \\
\text { Model } 2\end{array}$}} & \multicolumn{2}{|c|}{ Backward Step analysis } \\
\hline & & & & & Mod & \\
\hline & OR (CI) & SE (p) & OR (CI) & SE (p) & OR (CI) & SE (p) \\
\hline $60 / 79$ yrs. & $\begin{array}{c}1.27 \\
(1.04-1.55)\end{array}$ & $\begin{array}{c}0.13 \\
(0.02) *\end{array}$ & $\begin{array}{c}1.21 \\
(0.91-1.60)\end{array}$ & $\begin{array}{c}0.17 \\
(0.19)\end{array}$ & & \\
\hline White & $\begin{array}{c}1.36 \\
(1.15-1.61)\end{array}$ & $\begin{array}{c}0.12 \\
(0.00) *\end{array}$ & $\begin{array}{c}1.02 \\
(0.64-1.64)\end{array}$ & $\begin{array}{c}0.25 \\
(0.92)\end{array}$ & & \\
\hline Black & $\begin{array}{c}0.76 \\
(0.63-0.92)\end{array}$ & $\begin{array}{c}0.07 \\
(0.00) *\end{array}$ & Reference & & & \\
\hline WhiteWF & $\begin{array}{c}1.31 \\
(1.04-1.65)\end{array}$ & $\begin{array}{c}0.16 \\
(0.02) *\end{array}$ & $\begin{array}{c}1.08 \\
(0.67-1.74)\end{array}$ & $\begin{array}{c}0.26 \\
(0.75)\end{array}$ & & \\
\hline Latinos & $\begin{array}{c}0.51 \\
(0.35-0.74)\end{array}$ & $\begin{array}{c}0.10 \\
(0.00) *\end{array}$ & $\begin{array}{c}0.63 \\
(0.36-1.11)\end{array}$ & $\begin{array}{c}0.18 \\
(0.11)\end{array}$ & $\begin{array}{c}0.55 \\
(0.37-0.81)\end{array}$ & $\begin{array}{c}0.11 \\
(0.00) *\end{array}$ \\
\hline Latinas & $\begin{array}{c}0.55 \\
(0.37-0.80)\end{array}$ & $\begin{array}{c}0.11 \\
(0.00) *\end{array}$ & $\begin{array}{c}0.71 \\
(0.42-1.21)\end{array}$ & $\begin{array}{c}0.19 \\
(0.21)\end{array}$ & & \\
\hline Not HS grad & $\begin{array}{c}0.56 \\
(0.43-0.72)\end{array}$ & $\begin{array}{c}0.07 \\
(0.00) *\end{array}$ & Reference & & & \\
\hline HS grad & $\begin{array}{c}0.77 \\
(0.64-0.92)\end{array}$ & $\begin{array}{c}0.07 \\
(0.00) *\end{array}$ & $\begin{array}{c}0.95 \\
(0.65-1.40)\end{array}$ & $\begin{array}{c}0.19 \\
(0.81)\end{array}$ & & \\
\hline Post HS grad & $\begin{array}{c}1.60 \\
(1.36-1.89)\end{array}$ & $\begin{array}{c}0.14 \\
(0.00) *\end{array}$ & $\begin{array}{c}1.35 \\
(0.93-1.96)\end{array}$ & $\begin{array}{c}0.26 \\
(0.15)\end{array}$ & $\begin{array}{c}1.42 \\
(1.19-1.70)\end{array}$ & $\begin{array}{c}0.13 \\
(0.00) *\end{array}$ \\
\hline Computer & $\begin{array}{c}1.56 \\
(1.27-1.91)\end{array}$ & $\begin{array}{c}0.16 \\
(0.00) *\end{array}$ & $\begin{array}{c}1.25 \\
(0.78-2.0)\end{array}$ & $\begin{array}{c}0.30 \\
(0.36)\end{array}$ & $\begin{array}{c}1.26 \\
(1.01-1.57)\end{array}$ & $\begin{array}{c}0.14 \\
(0.04) *\end{array}$ \\
\hline ComputerWF & $\begin{array}{c}1.25 \\
(1.06-1.46)\end{array}$ & $\begin{array}{c}0.10 \\
(0.01) *\end{array}$ & $\begin{array}{c}1.14 \\
(0.71-1.83)\end{array}$ & & & \\
\hline Income & & & & & & \\
\hline $\min / 25,000$ & $\begin{array}{c}0.77 \\
(0.61-0.97)\end{array}$ & $\begin{array}{c}0.09 \\
(0.03) *\end{array}$ & Reference & & & \\
\hline $25,001 / 50,000$ & $\begin{array}{c}0.75 \\
(0.62-0.90)\end{array}$ & $\begin{array}{c}0.07 \\
(0.00) *\end{array}$ & $\begin{array}{c}0.66 \\
(0.48-0.91)\end{array}$ & $\begin{array}{c}0.11 \\
(0.01) *\end{array}$ & & \\
\hline $50,001 / 100,000$ & $\begin{array}{c}1.03 \\
(0.87-1.21)\end{array}$ & $\begin{array}{c}0.09 \\
(0.74)\end{array}$ & & & & \\
\hline $100,001 / \max$ & $\begin{array}{c}1.44 \\
(1.21-1.71)\end{array}$ & $\begin{array}{c}0.13 \\
(0.00) *\end{array}$ & $\begin{array}{c}0.91 \\
(0.71-1.16)\end{array}$ & $\begin{array}{c}0.11 \\
(0.45)\end{array}$ & & \\
\hline Wealth & & & & & & \\
\hline $\min / 25,000$ & $\begin{array}{c}0.76 \\
(0.64-0.89)\end{array}$ & $\begin{array}{c}0.06 \\
(0.00) *\end{array}$ & Reference & & & \\
\hline $25,001 / 50,000$ & $\begin{array}{c}0.76 \\
(0.62-0.92)\end{array}$ & $\begin{array}{c}0.08 \\
(0.01) *\end{array}$ & $\begin{array}{c}1.10 \\
(0.80-1.52)\end{array}$ & $\begin{array}{c}0.18 \\
(0.55)\end{array}$ & & \\
\hline $100,001 / 500,000$ & $\begin{array}{c}1.31 \\
(1.11-1.56)\end{array}$ & $\begin{array}{c}0.11 \\
(0.00) *\end{array}$ & $\begin{array}{c}1.53 \\
(1.14-2.04)\end{array}$ & $\begin{array}{c}0.23 \\
(0.01) *\end{array}$ & $\begin{array}{c}1.43 \\
(1.18-1.72)\end{array}$ & $\begin{array}{c}0.13 \\
(0.00) *\end{array}$ \\
\hline $500,001 / \max$ & $\begin{array}{c}1.48 \\
(1.19-1.84)\end{array}$ & $\begin{array}{c}0.16 \\
(0.00) *\end{array}$ & $\begin{array}{c}1.53 \\
(1.07-2.19)\end{array}$ & $\begin{array}{c}0.28 \\
(0.02) *\end{array}$ & $\begin{array}{c}1.47 \\
(1.16-1.87)\end{array}$ & $\begin{array}{c}0.18 \\
(0.00) *\end{array}$ \\
\hline
\end{tabular}

Source: Weighted data from the Panel Study of Income Dynamics; * $p<0.05$; Note: to conserve space, the nonstatistically significant variables in Univariate Model were omitted: Gender, Ages (14/39 yrs., 40/59 yrs., 80/max yrs.), Asian, BlackWF, AsianWF, Married, ReligiousHD, ReligiousWF, RetireWF, House, Child, City, Employment, Medcosts data were not shown in table. 


\subsection{What Factors Influence U.S. Charitable giving to Organizations Serving Youth?}

Because of the vulnerability of children and youth during a major recession, especially those already in need due to poverty and related issues, the set of independent variables was examined for possible associations with charitable giving to U.S. organizations serving youth (See Table 4). Chi-square results showed several independent variables associated with giving to organizations serving the most needy Americans. These included the marital status of the household head, the age of the household head, age of wife, the race of household head, the race of wife, the education level of the household head, total family income, total household wealth, the employment status of the head, whether or not the household head owns a computer, whether or not the wife owns a computer, the age at which the wife plans to retire ("stop working"), and total household medical costs. In addition, the "region" of the country in which the household resides as well as the degree of urbanicity of the residence approached significance at the $p<0.05$ level.

The results of subsequent analysis using backward step regression showed several of these independent variables to be significant predictors of U.S. household charitable giving to U.S. organizations serving youth. See Table 6 . These predictors were age, lived in a city or not, whether or not this person owned a computer, income level and total household wealth. Heads of households living in a city were $30 \%$ less likely ( $\mathrm{OR}=0.68 ; p=0.002$ ) compared to non-city dwellers to donate to organizations serving youth. Household heads aged 60 to 79 were more likely ( $\mathrm{OR}=1.37 ; p=0.02$ ) likely to make a charitable donation to organizations serving youth. Once again computer ownership was a significant predictor. Donors owning a computer were about one and half times $(\mathrm{OR}=1.54$; $p=0.01)$ as likely to give to youth organizations. Those with annual incomes over $\$ 100,000$ $(\mathrm{OR}=1.45 ; p=0.002)$ were more likely to give. And wealth was a significant predictor. Households with total wealth of over a half million dollars were almost twice as likely $(\mathrm{OR}=1.93 ; p=0.00)$ to give to youth organizations.

Table 6. Logistic models predicting charitable giving to youth organizations.

\begin{tabular}{lcccccc}
\hline & \multicolumn{2}{c}{ Univariate analysis } & \multicolumn{2}{c}{ Multivariate analysis } & \multicolumn{2}{c}{ Backward Step analysis } \\
\hline & \multicolumn{2}{c}{ Model 1 } & \multicolumn{2}{c}{ Model 2 } & \multicolumn{2}{c}{ Model 3 } \\
\hline \multirow{2}{*}{$14 / 39$ yrs. } & 0.64 & SE $(\mathbf{p})$ & OR $(\mathbf{C I})$ & SE $(\mathbf{p})$ & OR $(\mathbf{C I})$ & SE $(\mathbf{p})$ \\
& $(0.51-0.80)$ & $(0.00)^{*}$ & Reference & & & \\
\multirow{2}{*}{$60 / 79$ yrs. } & 1.49 & 0.19 & 1.31 & 0.18 & 1.37 & 0.18 \\
& $(1.17-1.91)$ & $(0.00)^{*}$ & $(1.00-1.73)$ & $(0.06)$ & $(1.05-1.78)$ & $(0.02)^{*}$ \\
White & 1.61 & 0.19 & 1.18 & 0.32 & & \\
\multirow{2}{*}{ Black } & $(1.27-2.04)$ & $(0.00)^{*}$ & $(0.69-2.01)$ & $(0.54)$ & & \\
& 0.61 & 0.08 & 1.04 & 0.30 & & \\
\hline
\end{tabular}


Table 6. Cont.

\begin{tabular}{|c|c|c|c|c|c|c|}
\hline & \multirow{2}{*}{\multicolumn{2}{|c|}{$\begin{array}{c}\text { Univariate analysis } \\
\text { Model } 1\end{array}$}} & \multirow{2}{*}{\multicolumn{2}{|c|}{$\begin{array}{c}\text { Multivariate analysis } \\
\text { Model } 2\end{array}$}} & \multirow{2}{*}{\multicolumn{2}{|c|}{$\begin{array}{c}\text { Backward Step analysis } \\
\text { Model } 3\end{array}$}} \\
\hline & & & & & & \\
\hline & OR (CI) & SE (p) & OR (CI) & SE (p) & OR (CI) & SE (p) \\
\hline Asian & $\begin{array}{c}0.27 \\
(0.07-0.98)\end{array}$ & $\begin{array}{c}0.18 \\
(0.05)^{*}\end{array}$ & Reference & & & \\
\hline Married & $\begin{array}{c}1.54 \\
(1.24-1.92)\end{array}$ & $\begin{array}{c}0.17 \\
(0.00) *\end{array}$ & $\begin{array}{c}1.17 \\
(0.79-1.74)\end{array}$ & $\begin{array}{c}0.24 \\
(0.42)\end{array}$ & & \\
\hline Not HS Grad & $\begin{array}{c}0.64 \\
(0.44-0.93)\end{array}$ & $\begin{array}{c}0.12 \\
(0.02) *\end{array}$ & Reference & & & \\
\hline HS Grad & $\begin{array}{c}0.73 \\
(0.57-0.93)\end{array}$ & $\begin{array}{c}0.09 \\
(0.01) *\end{array}$ & $\begin{array}{c}0.99 \\
(0.65-1.51)\end{array}$ & $\begin{array}{c}0.21 \\
(0.97)\end{array}$ & & \\
\hline Post HS Grad & $\begin{array}{c}1.57 \\
(1.25-1.96)\end{array}$ & $\begin{array}{c}0.18 \\
(0.00) *\end{array}$ & $\begin{array}{c}1.27 \\
(0.85-1.90)\end{array}$ & $\begin{array}{c}0.26 \\
(0.23)\end{array}$ & & \\
\hline City & $\begin{array}{c}0.69 \\
(0.54-0.88)\end{array}$ & $\begin{array}{c}0.09 \\
(0.00) *\end{array}$ & $\begin{array}{c}0.72 \\
(0.55-93)\end{array}$ & $\begin{array}{c}0.10 \\
(0.01) *\end{array}$ & $\begin{array}{c}0.68 \\
(0.53-0.87)\end{array}$ & $\begin{array}{c}0.09 \\
(0.00) *\end{array}$ \\
\hline Computer & $\begin{array}{c}1.75 \\
(1.29-2.38)\end{array}$ & $\begin{array}{c}0.27 \\
(0.00) *\end{array}$ & $\begin{array}{c}1.36 \\
(0.93-1.98)\end{array}$ & $\begin{array}{c}0.26 \\
(0.11)\end{array}$ & $\begin{array}{c}1.54 \\
(1.12-2.13)\end{array}$ & $\begin{array}{c}0.25 \\
(0.01) *\end{array}$ \\
\hline ComputerWF & $\begin{array}{c}1.54 \\
(1.25-1.91)\end{array}$ & $\begin{array}{c}0.17 \\
(0.00) *\end{array}$ & $\begin{array}{c}1.01 \\
(0.67-1.53)\end{array}$ & & & \\
\hline Income & & & & & & \\
\hline $\mathrm{min} / 25,000$ & $\begin{array}{c}0.59 \\
(0.41-0.84)\end{array}$ & $\begin{array}{c}0.11 \\
(0.00) *\end{array}$ & Reference & & & \\
\hline $25,001 / 50,000$ & $\begin{array}{c}0.73 \\
(0.56-0.94)\end{array}$ & $\begin{array}{c}0.10 \\
(0.02) *\end{array}$ & $\begin{array}{c}0.99 \\
(0.73-1.33)\end{array}$ & $\begin{array}{c}0.15 \\
(0.95)\end{array}$ & & \\
\hline $50,001 / 100,000$ & $\begin{array}{c}0.93 \\
(0.75-1.15)\end{array}$ & $\begin{array}{c}0.10 \\
(0.50)\end{array}$ & & & & \\
\hline $100,001 / \max$ & $\begin{array}{c}1.75 \\
(1.41-2.17)\end{array}$ & $\begin{array}{c}0.19 \\
(0.00) *\end{array}$ & $\begin{array}{c}1.33 \\
(1.02-1.74)\end{array}$ & $\begin{array}{c}0.18 \\
(0.03) *\end{array}$ & $\begin{array}{c}1.45 \\
(1.15-1.82)\end{array}$ & $\begin{array}{c}0.17 \\
(0.00) *\end{array}$ \\
\hline Wealth & & & & & & \\
\hline $\mathrm{min} / 25,000$ & $\begin{array}{c}0.53 \\
(0.42-0.68)\end{array}$ & $\begin{array}{c}0.06 \\
(0.00) *\end{array}$ & Reference & & & \\
\hline $25,001 / 50,000$ & $\begin{array}{c}0.78 \\
(0.60-1.03)\end{array}$ & $\begin{array}{c}0.11 \\
(0.08)\end{array}$ & & & & \\
\hline $100,001 / 500,000$ & $\begin{array}{c}1.20 \\
(0.96-1.49)\end{array}$ & $\begin{array}{c}0.13 \\
(0.11)\end{array}$ & & & & \\
\hline $500,001 / \max$ & $\begin{array}{c}2.38 \\
(1.85-3.05) \\
\end{array}$ & $\begin{array}{c}0.30 \\
(0.00) * \\
\end{array}$ & $\begin{array}{c}1.74 \\
(1.31-2.31) \\
\end{array}$ & $\begin{array}{c}0.25 \\
(0.00) *\end{array}$ & $\begin{array}{c}1.93 \\
(1.47-2.53) \\
\end{array}$ & $\begin{array}{c}0.27 \\
(0.00) * \\
\end{array}$ \\
\hline
\end{tabular}

Source: Weighted data from the Panel Study of Income. Note. $\mathrm{SE}=$ standard error. $\mathrm{OR}=$ odds ratio. $(\mathrm{p})=p$ value $*<0.05$. Note: to conserve space, the nonstatistically significant variables in Univariate Model: Gender, Ages (40/59 yrs., 80/max yrs.), WhiteWF, BlackWF, AsianWF, Latinos, Latinas, Married, ReligiousHD, ReligiousWF, RetireWF, House, Child, Employment, Medcosts data were not shown in table. 


\subsection{What Factors Influence U.S. Charitable Giving to International Organizations?}

The Great Recession negatively impacted not only U.S. residents, but also people all over the world. Many of these people already suffer from poverty, war, and disease. Because of this vulnerability, the previously described set of independent variables was also tested for possible associations with the dependent variable, charitable giving to international organizations, many of which serve people in need of basic necessities like food, shelter, and basic health care. (See Table 4) Chi-square results showed several independent variables associated with giving to international organizations. These variables were the age of the household head and wife, total family income, the race of household head and wife, the education level of the household head, household size, whether or not the household head owns a computer, household wealth, and the total household medical costs. What is more, the region in which the household resides approached significance at the $p<0.05$ level.

The results of subsequent analysis using backward step regression showed several of these independent variables to be significant predictors of U.S. household charitable giving to international organizations serving those in need. See Table 7. These were the age of household head, race of wife, education level of the household head as well as total household wealth. More specifically, relatively young household heads aged 39 or younger were less likely $(\mathrm{OR}=0.60 ; p=0.037)$ to make a donation as older household heads. In contrast, when the race of the wife of the household head was Asian, donations were three times higher $(\mathrm{OR}=3.41 ; p=0.012$ ) compared to non-Asian wives who donated to international organizations. Also, household heads with more than a high school education $(\mathrm{OR}=2.43 ; p=0.000)$ were much more likely to make a charitable gift to an international organization. And finally, households with over a half million dollars in total wealth were twice as likely $(\mathrm{OR}=2.06 ; p=0.001)$ to give to international organizations.

Table 7. Logistic models predicting charitable giving to international organization.

\begin{tabular}{|c|c|c|c|c|c|c|}
\hline & \multirow{2}{*}{\multicolumn{2}{|c|}{$\begin{array}{c}\text { Univariate analysis } \\
\text { Model } 1\end{array}$}} & \multirow{2}{*}{\multicolumn{2}{|c|}{$\begin{array}{c}\text { Multivariate analysis } \\
\text { Model 2 } \\
\end{array}$}} & \multirow{2}{*}{\multicolumn{2}{|c|}{$\begin{array}{c}\text { Backward Step analysis } \\
\text { Model } 3 \\
\end{array}$}} \\
\hline & & & & & & \\
\hline & OR (CI) & SE (p) & OR (CI) & SE (p) & OR (CI) & SE (p) \\
\hline 14/39 yrs. & $\begin{array}{c}0.60 \\
(0.43-0.85)\end{array}$ & $\begin{array}{c}0.10 \\
(0.00) *\end{array}$ & $\begin{array}{c}0.65 \\
(0.40-1.07)\end{array}$ & $\begin{array}{c}0.17 \\
(0.09)\end{array}$ & $\begin{array}{c}0.60 \\
(0.37-0.97)\end{array}$ & $\begin{array}{c}0.15 \\
(0.04) *\end{array}$ \\
\hline White & $\begin{array}{c}1.44 \\
(1.03-2.03)\end{array}$ & $\begin{array}{c}0.25 \\
(0.03) *\end{array}$ & $\begin{array}{c}1.22 \\
(0.68-2.16)\end{array}$ & $0.36(0.51)$ & & \\
\hline Black & $\begin{array}{c}0.43 \\
(0.29-0.65)\end{array}$ & $\begin{array}{c}0.09 \\
(0.00) *\end{array}$ & Reference & & & \\
\hline AsianWF & $\begin{array}{c}3.57 \\
(1.54-8.28)\end{array}$ & $\begin{array}{c}1.53 \\
(0.00) *\end{array}$ & $\begin{array}{c}4.08 \\
(1.46-11.38)\end{array}$ & $\begin{array}{c}2.13 \\
(0.01) *\end{array}$ & $\begin{array}{c}3.41 \\
(1.30-8.94)\end{array}$ & $\begin{array}{c}1.68 \\
(0.01) *\end{array}$ \\
\hline House & $\begin{array}{c}1.46 \\
(1.08-1.99)\end{array}$ & $\begin{array}{c}0.23 \\
(0.01) *\end{array}$ & $\begin{array}{c}1.27 \\
(0.84-1.93)\end{array}$ & $\begin{array}{c}0.27 \\
(0.26)\end{array}$ & & \\
\hline NotHSGrad & $\begin{array}{c}0.31 \\
(0.14-0.67)\end{array}$ & $\begin{array}{c}0.12 \\
(0.00) *\end{array}$ & Reference & & & \\
\hline HSGrad & $\begin{array}{c}0.48 \\
(0.32-0.72)\end{array}$ & $\begin{array}{c}0.10 \\
(0.00) *\end{array}$ & $\begin{array}{c}1.58 \\
(0.54-4.61)\end{array}$ & $\begin{array}{c}0.86 \\
(0.40)\end{array}$ & & \\
\hline PostHSGrad & $\begin{array}{c}2.73 \\
(1.88-3.97)\end{array}$ & $\begin{array}{c}0.52 \\
(0.00) *\end{array}$ & $\begin{array}{c}3.23 \\
(1.18-8.84)\end{array}$ & $\begin{array}{c}1.66 \\
(0.02) *\end{array}$ & $\begin{array}{c}2.43 \\
(1.52-3.89)\end{array}$ & $\begin{array}{c}0.58 \\
(0.00) *\end{array}$ \\
\hline Computer & $\begin{array}{c}1.57 \\
(1.01-2.46) \\
\end{array}$ & $\begin{array}{c}0.36 \\
(0.05) * \\
\end{array}$ & $\begin{array}{c}0.81 \\
(0.42-1.58) \\
\end{array}$ & $\begin{array}{c}0.27 \\
(0.54) \\
\end{array}$ & & \\
\hline
\end{tabular}


Table 7. Cont.

\begin{tabular}{|c|c|c|c|c|c|c|}
\hline & \multirow{2}{*}{\multicolumn{2}{|c|}{$\begin{array}{c}\text { Univariate analysis } \\
\text { Model } 1\end{array}$}} & \multicolumn{2}{|c|}{ Multivariate analysis } & \multicolumn{2}{|c|}{ Backward Step analysis } \\
\hline & & & Moc & & Mod & \\
\hline & OR (CI) & SE (p) & OR (CI) & SE (p) & OR (CI) & SE (p) \\
\hline \multicolumn{7}{|l|}{ Income } \\
\hline $25,001 / 50,000$ & $\begin{array}{c}0.59 \\
(0.40-0.89)\end{array}$ & $\begin{array}{c}0.12 \\
(0.01) *\end{array}$ & Reference & & & \\
\hline $100,001 / \max$ & $\begin{array}{c}1.97 \\
(1.45-2.66)\end{array}$ & $\begin{array}{c}0.30 \\
(0.00) *\end{array}$ & $\begin{array}{c}1.31 \\
(0.89-1.93)\end{array}$ & $\begin{array}{c}0.26 \\
(0.18)\end{array}$ & & \\
\hline \multicolumn{7}{|l|}{ Wealth } \\
\hline $\min / 25,000$ & $\begin{array}{c}0.56 \\
(0.40-0.79)\end{array}$ & $\begin{array}{c}0.10 \\
(0.00) *\end{array}$ & Reference & & & \\
\hline $25,001 / 50,000$ & $\begin{array}{c}0.75 \\
(0.50-1.13)\end{array}$ & $\begin{array}{c}0.16 \\
(0.17)\end{array}$ & $\begin{array}{c}0.71 \\
(0.37-1.36)\end{array}$ & $\begin{array}{c}0.24 \\
(0.30)\end{array}$ & & \\
\hline $500,001 / \max$ & $\begin{array}{c}2.64 \\
(1.89-3.68)\end{array}$ & $\begin{array}{c}0.45 \\
(0.00) *\end{array}$ & $\begin{array}{c}1.71 \\
(1.10-2.66)\end{array}$ & $\begin{array}{c}0.39 \\
(0.02) *\end{array}$ & $\begin{array}{c}2.06 \\
(1.35-3.15)\end{array}$ & $\begin{array}{c}0.45 \\
(0.00) *\end{array}$ \\
\hline
\end{tabular}

Source: Weighted data from the Panel Study of Income. SE = standard error. OR = odds ratio. $(\mathrm{p})=p$ value * $<0.05$. Note: to conserve space, the nonstatistically significant variables in the Univariate Model: Gender, Ages (40/59 yrs., 60/79 yrs., 80/max yrs.), Asian, WhiteWF, BlackWF, Latinos, Latinas, Married, ReligiousHD, ReligiousWF, RetireWF, Child, City, Employment, ComputerWF, Medcosts, Income (min/25000, 50001/100000), Wealth (100001/500000) data were not shown in table.

\subsection{What Factors Influence U.S. Charitable Giving to Combined Purpose Organizations?}

"Combined purpose" organizations in this sample are organizations that run federated fundraising campaigns, and then distribute the funds raised to various nonprofit organizations. Examples include the United Way, the Jewish Federations of North America (formerly United Jewish Appeal), and Catholic Charities. With local United Way agencies, for example, the funds raised are then allocated to multiple service providers addressing priority needs such as shelter or child care in the local community. Chi-square results showed several independent variables associated with giving to combined purpose organizations (at the $p<0.05$ significance level or greater). These variables were sex of the household head; age of household head; whether the household head was Latino and married to a Latina; whether or not the household head and wife expressed a religious preference; household medical costs, household income; household wealth, marital status, employment status, and education level of household head, region of household residence, and household head and wife's computer ownership.

The results of subsequent analysis using backward step regression, however, showed the following independent variables to be significant predictors of U.S. household charitable giving to combined purpose organizations such as United Way. (See Table 8) These predictors were whether or not the household head expressed a religious preference as well as the household head's computer ownership, employment status, income level, and total household wealth. Latinos were less likely (OR $=0.58$; $p=0.011)$ compared to non-Latinos to make a charitable donation. Household heads with a religious preference (for any denomination) were more likely to donate ( $\mathrm{OR}=1.37 ; p=0.026)$. Similarly, those with annual incomes over $\$ 100,000(\mathrm{OR}=1.43 ; p=0.000)$, and those with household wealth exceeding $\$ 500,000$ (OR $=1.45 ; p=0.002)$ were more likely than others in the sample to donate to 
combined purpose organizations. Further, household heads who owned a computer were much more likely $(\mathrm{OR}=1.78 ; p=0.000)$ to give to these organizations.

Table 8. Logistic models predicting charitable giving to combo organizations.

\begin{tabular}{|c|c|c|c|c|c|c|}
\hline & \multirow{2}{*}{\multicolumn{2}{|c|}{$\begin{array}{c}\text { Univariate analysis } \\
\text { Model } 1\end{array}$}} & \multirow{2}{*}{\multicolumn{2}{|c|}{$\begin{array}{c}\text { Multivariate analysis } \\
\text { Model } 2\end{array}$}} & \multirow{2}{*}{\multicolumn{2}{|c|}{$\begin{array}{c}\text { Backward Step analysi } \\
\text { Model } 3\end{array}$}} \\
\hline & & & & & & \\
\hline & OR (CI) & SE (p) & OR (CI) & SE (p) & OR (CI) & SE (p) \\
\hline Gender & $\begin{array}{c}1.27 \\
(1.06-1.53)\end{array}$ & $\begin{array}{c}0.12 \\
(0.01) *\end{array}$ & $\begin{array}{c}0.91 \\
(0.67-1.22)\end{array}$ & $\begin{array}{c}0.14 \\
(0.52)\end{array}$ & & \\
\hline $14 / 39$ yrs. & $\begin{array}{c}0.78 \\
(0.66-0.92)\end{array}$ & $\begin{array}{c}0.07 \\
(0.00) *\end{array}$ & Reference & & & \\
\hline $40 / 59$ yrs. & $\begin{array}{c}1.24 \\
(1.05-1.46)\end{array}$ & $\begin{array}{c}0.10 \\
(0.01) *\end{array}$ & $\begin{array}{c}1.04 \\
(0.87-1.25)\end{array}$ & $\begin{array}{c}0.10 \\
(0.65)\end{array}$ & & \\
\hline Latinos & $\begin{array}{c}0.47 \\
(0.31-0.71)\end{array}$ & $\begin{array}{c}0.10 \\
(0.00) *\end{array}$ & $\begin{array}{c}0.65 \\
(0.40-1.04)\end{array}$ & $\begin{array}{c}0.16 \\
(0.07)\end{array}$ & $\begin{array}{c}0.58 \\
(0.38-0.88)\end{array}$ & $\begin{array}{c}0.12 \\
(0.01) *\end{array}$ \\
\hline Latinas & $\begin{array}{c}0.65 \\
(0.43-0.96)\end{array}$ & $\begin{array}{c}0.13 \\
(0.03) *\end{array}$ & $\begin{array}{c}0.90 \\
(0.52-1.56)\end{array}$ & $\begin{array}{c}0.25 \\
(0.71)\end{array}$ & & \\
\hline Married & $\begin{array}{c}1.37 \\
(1.16-1.62)\end{array}$ & $\begin{array}{c}0.12 \\
(0.00) *\end{array}$ & $\begin{array}{c}0.97 \\
(0.65-1.46)\end{array}$ & $\begin{array}{c}0.20 \\
(0.90)\end{array}$ & & \\
\hline ReligiousHD & $\begin{array}{c}1.31 \\
(1.0-1.71)\end{array}$ & $\begin{array}{c}0.18 \\
(0.05) *\end{array}$ & $\begin{array}{c}1.37 \\
(1.01-1.85)\end{array}$ & $\begin{array}{c}0.21 \\
(0.04) *\end{array}$ & $\begin{array}{c}1.37 \\
(1.04-1.80)\end{array}$ & $\begin{array}{c}0.19 \\
(0.03) *\end{array}$ \\
\hline ReligiousWF & $\begin{array}{c}1.39 \\
(1.18-1.65)\end{array}$ & $\begin{array}{c}0.12 \\
(0.00) *\end{array}$ & $\begin{array}{c}1.37 \\
(0.92-2.02)\end{array}$ & $\begin{array}{c}0.27 \\
(0.12)\end{array}$ & & \\
\hline Not HS Grad & $\begin{array}{c}0.58 \\
(0.44-0.77)\end{array}$ & $\begin{array}{c}0.08 \\
(0.00) *\end{array}$ & Reference & & & \\
\hline HS Grad & $\begin{array}{c}0.85 \\
(0.71-1.02)\end{array}$ & $\begin{array}{c}0.08 \\
(0.08)\end{array}$ & & & & \\
\hline Post HS Grad & $\begin{array}{c}1.44 \\
(1.21-1.70)\end{array}$ & $\begin{array}{c}0.12 \\
(0.00) *\end{array}$ & $\begin{array}{c}1.20 \\
(0.99-1.45)\end{array}$ & $\begin{array}{c}0.12 \\
(0.07)\end{array}$ & & \\
\hline City & $\begin{array}{c}0.91 \\
(0.75-1.09)\end{array}$ & $\begin{array}{c}0.08 \\
(0.29)\end{array}$ & & & & \\
\hline Computer & $\begin{array}{c}1.97 \\
(1.58-2.47)\end{array}$ & $\begin{array}{c}0.23 \\
(0.00) *\end{array}$ & $\begin{array}{c}1.70 \\
(1.27-2.26)\end{array}$ & $\begin{array}{c}0.25 \\
(0.00) *\end{array}$ & $\begin{array}{c}1.78 \\
(1.41-2.26)\end{array}$ & $\begin{array}{c}0.21 \\
(0.00) *\end{array}$ \\
\hline ComputerWF & $\begin{array}{c}1.45 \\
(1.23-1.70)\end{array}$ & $\begin{array}{c}0.12 \\
(0.00) *\end{array}$ & $\begin{array}{c}0.91 \\
(0.64-1.31)\end{array}$ & $\begin{array}{c}0.17 \\
(0.63)\end{array}$ & & \\
\hline Employment & $\begin{array}{c}1.37 \\
(1.14-1.64)\end{array}$ & $\begin{array}{c}0.13 \\
(0.00) *\end{array}$ & $\begin{array}{c}1.13 \\
(0.92-1.39)\end{array}$ & $0.12(0.23)$ & & \\
\hline \multicolumn{7}{|l|}{ Income } \\
\hline $\min / 25,000$ & $\begin{array}{c}0.43 \\
(0.33-0.56)\end{array}$ & $\begin{array}{c}0.06 \\
(0.00)\end{array}$ & Reference & & & \\
\hline $25,001 / 50,000$ & $\begin{array}{c}0.75 \\
(0.62-0.91)\end{array}$ & $\begin{array}{c}0.07 \\
(0.00)\end{array}$ & $\begin{array}{c}0.97 \\
(0.78-1.22)\end{array}$ & $\begin{array}{c}0.11 \\
(0.80)\end{array}$ & & \\
\hline $100,001 / \max$ & $\begin{array}{c}1.77 \\
(1.49-2.11)\end{array}$ & $\begin{array}{c}0.16 \\
(0.00)\end{array}$ & $\begin{array}{c}1.32 \\
(1.05-1.66)\end{array}$ & $\begin{array}{c}0.15 \\
(0.02) *\end{array}$ & $\begin{array}{c}1.43 \\
(1.18-1.74)\end{array}$ & $\begin{array}{c}0.14 \\
(0.00) *\end{array}$ \\
\hline \multicolumn{7}{|l|}{ Wealth } \\
\hline $\min / 25,000$ & $\begin{array}{c}0.69 \\
(0.58-0.82)\end{array}$ & $\begin{array}{c}0.06 \\
(0.00) *\end{array}$ & Reference & & & \\
\hline $500,001 / \max$ & $\begin{array}{c}1.80 \\
(1.45-2.24)\end{array}$ & $\begin{array}{c}0.20 \\
(0.00)\end{array}$ & $\begin{array}{c}1.43 \\
(1.11-1.84)\end{array}$ & $\begin{array}{c}0.18 \\
(0.00) *\end{array}$ & $\begin{array}{c}1.45 \\
(1.14-1.84) \\
\end{array}$ & $\begin{array}{c}0.18 \\
(0.00) *\end{array}$ \\
\hline
\end{tabular}


Source: Weighted data from the Panel Study of Income. SE = standard error. OR = odds ratio. $(\mathrm{p})=p$ value $*<0.05$. Note: to conserve space nonstatistically significant variables in Univariate Model were omitted: Ages (60/79 yrs., 80/max yrs.), White, Black, Asian, WhiteWF, BlackWF, AsianWF, RetireWF, House, Child, City, Medcosts, Income (50,001/100,000), Wealth $(25,001 / 50,000,100,001 / 500,000)$ data were not shown in table.

\section{Discussion}

The factors influencing U.S. charitable giving in this study varied across the four categories of human service organization with the exception of total household wealth. That is, total household wealth was found to be a significant in the backward step regression examining donations to organizations serving the needy, youth organizations, international charities, and combined purpose agencies such as United Way. In addition to total household wealth, significant factors influencing charitable giving to organizations serving the needy in this study were the household head's race, education level, and computer ownership. For youth-service agencies, the significant factors were the household head's age, location of residence, computer ownership, and income level. Regarding giving to international aid organizations, those significant factors were the household head's age, education level, and the race of the spouse, while for combined purpose organizations, other significant factors consisted of the household head's employment status, income level, computer ownership, and whether or not the household head expressed a religious preference.

Other than wealth, the only variable of significance in more than two categories of nonprofit human service beneficiary was computer ownership. The fact that computer ownership was a significant predictor of giving to combined purpose organizations, youth services, and organizations providing basic necessities to the needy is consistent with the recent Mano study findings [20] and suggests the growing influence of personal computers and online solicitation as a vehicle for charitable giving. It also indicates that the previously described "charitable divide" should not be the only "divide" of interest to nonprofit administrators. The "digital divide" between the "haves" and "have nots" in access to computers and online technologies should be a concern for nonprofit management as well.

With respect to the influence of wealth, in this study, those households with wealth estimated between $\$ 100,001$ and $\$ 500,000$ were about one and a half times more likely ( $\mathrm{OR}=1.43 ; p=0.00)$ to make a donation to organizations providing basic necessities such as food and shelter; households with over a half million dollars in wealth were also about one and a half times more likely $(\mathrm{OR}=1.47$; $p=0.002$ ) to give to organizations serving the most needy. Likewise, those with household wealth exceeding $\$ 500,000$ were more likely $(\mathrm{OR}=1.45 ; p=0.002)$ to give to combined purpose organizations. Wealth was also a significant predictor of giving to youth-service agencies. Households with total wealth of over a half million dollars were almost twice as likely $(\mathrm{OR}=1.93 ; p=0.00)$ to give to youth organizations. Similarly, households with over a half million dollars in total wealth were twice as likely $(\mathrm{OR}=2.06 ; p=0.001)$ to give to international organizations.

Given this dependence of private nonprofit human service agencies on the charity of wealthy Americans to meet increased service demands during a recession, the proportion of the total charitable contributions of these wealthy households that go to charities serving the most needy and vulnerable groups is particularly important. In other words, social advocates concerned about social and economic justice want to see a large share of the giving of wealthy households going to assist the most 
needy during a deep recession. In such crises when major societal institutions are threatened, charity - consistent with social exchange theory-would seem to benefit both givers and receivers. In this study, charities receiving the largest percentages of gifts from households with over $\$ 500,000$ in wealth were religion (43\%), combined purpose organizations such as United Way (40\%), and organizations providing basic necessities like food and shelter to the most needy (6\%). In addition, the categories of charities receiving the largest median gifts from households with over a half million dollars in wealth were religion ( $\$ 2000, n=535)$, combined purpose campaigns $(\$ 500, n=368)$, and organizations providing basic necessities to the most needy $(\$ 400, n=426$ ).

These findings are encouraging given the historic role of American churches in providing food and clothing to the poor. What is more, United Way, Jewish Federations of North America, and similar combined purpose organizations typically allocate funds to human service organizations serving the needy. One of United Way's three top priorities for funding allocations is "income" (along with education and health). By "income," United Way is referring to financial stability. That is, starting in 2008, United Way began a major initiative to help lower income households meet their basic needs, while gaining skills for long-term financial stability. Consequently, the organization has focused its funding programs related to employment, income support, savings and assets, manageable expenses as well as affordable housing. All are high priority items given the 2008 recession and its associated mortgage crisis [24]. Similarly, the Jewish Federations of North America distributes funds raised to senior programs involved with food, housing, and transportation [25]. Catholic Charities USA has embarked on a "campaign to reduce poverty." [26] In short, these combined purpose organizations raise and distribute funds to the most vulnerable groups.

While our study findings may be encouraging for human service administrators, the study does have inherent limitations. First, a cross-sectional study of U.S. donors is limited in its generalizability to other nations and time periods. Second, this study, which is a secondary analysis of quantitative survey data, is limited by the weaknesses of such research designs. Such limitations include the dependence on a given set of questionnaire items and the variables available in a given dataset for subsequent studies and variable measurement. Because of these limitations and given the findings of this study, future research should provide a more comprehensive and in depth examination of the growing influence of computer ownership and online technologies (including social media) on charitable giving $[19,20]$. Due to the "charitable divide," this future research should focus particularly on the characteristics and preferences of wealthy online donors in relation to combined purpose organizations and other human services.

\section{Implications for Administrative Practice}

There are several important implications of this study's findings for nonprofit administrators and advocates. One is the continuing importance of combined purpose organizations, many of which conduct annual federated fundraising campaigns. Often nonprofit organizations helping the destitute are small grassroots voluntary associations. Their small size and relative anonymity make it hard for them to compete for charitable dollars against larger, higher status organizations. Umbrella organizations like United Way, that collect and distribute funds to benefit multiple service organizations, are well-known brands, and therefore, particularly beneficial to these small nonprofits. The federated 
model of community fundraising and problem-solving continues to be an efficient and effective model, but faces increasing competition from online giving and changes in the overall U.S. economy. Today, using online giving, many corporations allow their employees to donate to whatever organization they prefer anywhere in the world. While this more open model has its benefits, it erodes the share of total charitable giving going to local workplace campaigns such as United Way. Many online givers, of course, give to organizations serving the most needy, both in the U.S. and internationally. However, they are also free to give to the arts, environment, or higher education, particularly when not making decisions in a workplace culture that emphasizes giving to local human services. Federated fundraising organizations like United Way and the Jewish Federations of North America need to compete more vigorously for online givers and for international charity funds. The finding in this study that household heads who owned a computer were much more likely to give to combined purpose organizations is a positive indicator for human service administrators concerned about international charitable giving. Further, United Way Worldwide, formed in 2009, and its International Donor Advised Giving Program begin to address the challenge by offering guidance (due diligence, grant oversight) to corporations and individuals wanting to donate to international nonprofit organizations.

Secondly, large corporations are more likely offer employees the opportunity to "give at the office" through payroll deduction and to hold workplace fundraising campaigns each year [13]. Yet, corporate downsizing and mergers became a salient economic trend starting with the Reagan Administration as U.S. corporations repositioned themselves to compete in a more global economy. Consequently, many suddenly unemployed middle managers started their own small businesses. The recent "Great Recession" produced similar results. Today, small businesses continue to make up the vast majority of American businesses. This demographic represents a challenge to social administrators in human services and organizations such as United Way, and a threat to our most needy citizens who depend on their services during hard economic times. Administrators in combined purpose organizations such as United Way need to develop better models and strategies for gaining support from small businesses.

Third, since large corporations are more likely offer employees the opportunity to "give at the office" through payroll deduction, these employees often choose to have a small amount of dollars take out from their checks on a bi-monthly or monthly basis [13]. "Monthly giving" has proven very effective in other countries, but is not used in the United States as much as it could be. Small amounts of money can be automatically transferred from the donor's debit or credit card in a way that is relatively painless, and therefore, sustainable for the donor. Such donors also make great prospects for future major gifts and planned giving. Nonprofit administrators find that monthly donations, because they are consistent and therefore, predictable, help them to set annual fundraising goals and manage expectations of board members. Yet, other than combined purpose organizations like United Way with its payroll deduction, nonprofit organizations are reluctant to approach donors with such an offer out of fear of appearing too intrusive. Still other nonprofit organizations believe that such "Monthly EFT Giving" programs must be expensive or time consuming to administer-even though vendors and software are available at reasonable costs. This may be particularly true for small-budget grassroots youth agencies and human service organizations providing basic necessities to the most destitute.

The growth of family and community foundations represents yet another alternative to the federated fundraising and allocation models of combined purpose organizations such as United Way and the Jewish Federations of North America. Wealthy families can maintain more control and decision-making 
in their philanthropy while receiving investment and tax consultation. The creation of foundations increased rapidly during the 1990s and early 2000s in the U.S.; this growth continued right up until the recession deepened in 2008 when foundation funding peaked. It took until 2011 for foundation funding to recover and surpass its 2008 peak. As of 2012, there were 76, 600 U.S. foundations. Community foundations typically fund a much broader array of causes than human services; consequently human service administrators and advocates need to be active as volunteers on the boards and committees of such foundations in order to stress the importance of human service giving-especially to agencies providing basic necessities to the most destitute during recessions [27].

Similarly, nonprofit human service administrators and staff need to take every opportunity to inform business and professional leaders to the fact that their individual nonprofit agencies benefit significantly from donations to combined purpose organizations. As corporations have become more strategic in their corporate contributions and individual donors have sought more control over decisions involving their charity, combined purpose organizations and their fundraising models can seem traditional and outdated - anything but "cutting edge." Yet, the results of this study indicate that such organizations remain critically important to human service nonprofits and the needy populations that benefit from their funds and services.

\section{Acknowledgments}

The authors would like to acknowledge the assistance of graduate student, Kaitlyn Schena.

\section{Author Contributions}

Both authors contributed equally to the manuscript.

\section{Conflicts of Interest}

The authors declare no conflict of interest.

\section{References}

1. Kanto, J. The Obamas; Little, Brown, and Company: New York, NY, USA, 2012.

2. Center on Philanthropy at Indiana University. Giving USA 2010: The Annual Report on Philanthropy for the Year 2009. Executive Summary; Giving USA Foundation: Glenview, IL, USA, 2010; p. 14.

3. Blau, P.M. Exchange and Power in Social Life; Transaction Publishers: Piscataway, NJ, USA, 1986.

4. Warner, J. The way we live now: The charitable-giving divide. New York Times Magazine, 20 August 2010. Available online: http://www.nytimes.com/2010/08/22/magazine/ 22FOB-wwln-t.html?_r=0 (accessed on 31 March 2014).

5. Edmondson, V.C.; Carroll, A.B. Giving back: An examination of the philanthropic motivations, orientations and activities of large black-owned businesses. J. Bus. Ethics 1999, 19, 171-179.

6. Marx, J.D. Women and human services giving. Soc. Work 2000, 45, $27-38$. 
7. Center on Philanthropy and Civil Society. African American Philanthropy Literature Review; Center on Philanthropy and Civil Society: New York, NY, USA, 2003; pp. 12-13.

8. Bekkers, R.; Wiepking, P. A literature review of empirical studies of philanthropy: Eight mechanisms that drive charitable giving. Nonprofit Volunt. Sect. Q. 2011, 40, 924-973.

9. Carter, V.B.; Marx, J.D. What motivates African-American charitable giving: Findings from a national sample. Adm. Soc. Work 2007, 31, 67-85.

10. Wang, L.; Graddy, E. Social Capital, Volunteering, and Charitable Giving. Voluntas: Int. J. Voluntary Nonprofit Org. 2008, 19, 23-42.

11. Marx, J.D.; Carter, V.B. Hispanic charitable giving: An opportunity for nonprofit development. Nonprofit Manag. Leadersh. 2008, 19, 173-187.

12. Wiepking, P. Democrats support international relief and the upper class donates to art? how opportunity, incentives and confidence affect donations to different types of charitable organizations. Soc. Sci. Res. 2010, 39, 1073-1087.

13. Osili, U.O.; Hirt, D.E.; Raghavan, S. Charitable giving inside and outside the workplace: The role of individual and firm characteristics. Int. J. Nonprofit Volunt. Sect. Mark. 2011, 16, 393-408.

14. Yörük, B. Do fundraisers select charitable donors based on gender and race? Evidence from survey data. J. Popul. Econ. 2011, 25, 219-243.

15. Center on Philanthropy at Indiana University. 2011 Study of High Net Worth Women's Philanthropy and the Impact of Women's Giving Networks; Center on Philanthropy: Indianapolis, IN, USA, 2012; pp. 1-31.

16. Wiepking, P.; Breeze, B. Feeling poor, acting stingy: The effect of money perceptions on charitable giving. Int. J. Nonprofit Volunt. Sect. Mark. 2012, 17, 13-24.

17. Kemp, E.; Kennett-Hensel, P.; Kees, J. Pulling on the heartstrings: Examining the effects of emotions and gender in persuasive appeals. J. Advert. 2013, 42, 69-79.

18. Clerkin, R.M.; Paarlberg, L.E.; Christensen, R.K.; Nesbit, R.A.; Tschirhart, M. Place, time, and philanthropy: Exploring geographic mobility and philanthropic engagement. Public Adm. Rev. 2013, 73, 97-106.

19. FirstGiving. Understanding online donors: Firstgiving donor insights 2007-2010. 2013. Available online: http://info.firstgiving.com/Portals/73888/docs/Understanding donor behavior.pdf (accessed on 27 December 2013).

20. Mano, R.S. Social media, social causes, giving behavior, and money contributions. Comput. Hum. Behav. 2014, 31, 287-293.

21. Heeringa, S.G.; Berglund, P.A.; Khan, A. Panel Study of Income Dynamics. Construction and Evaluation of the Longitudinal Individual and Family Weights. In Panel Study of Income Dynamics Technical Report; Survey Research Center, University of Michigan: Ann Arbor, MI, USA, 2011.

22. Menard, S.W. Applied Logistic Regression Analysis; Sage: Thousand Oaks, CA, USA, 1995.

23. Lynch, S. Missing Data (March 2013). Available online: http://www.princeton.edu/ slynch/ soc504missingdata.pdf (accessed on 22 May 2014).

24. United Way. Income, 2013. Available online: http://www.unitedway.org/our-work/ income (accessed on 27 December 2013). 
25. Jewish Federations of North America. Vulnerable populations, 2013. Available online: http://www.jewishfederations.org/vulnerable-populations.aspx (accessed on 28 December 2013).

26. Catholic Charities USA. Campaign to reduce poverty, 2013. Available online: http://www.catholiccharitiesusa.org/our-solutions/campaign-to-reduce-poverty/ (accessed on 28 December 2013).

27. Lawrence, S. Foundation growth and giving estimates. Foundation Center: New York, NY, USA, 2012. Available online: http://foundationcenter.org/gainknowledge/research/pdf/fgge12.pdf (accessed on 28 December 2013).

(C) 2014 by the authors; licensee MDPI, Basel, Switzerland. This article is an open access article distributed under the terms and conditions of the Creative Commons Attribution license (http://creativecommons.org/licenses/by/3.0/). 